\title{
EFFECT OF CAMEL MILK ON DIABETIC NEPHROPATHY IN STREPTOZOTOCIN - INDUCED DIABETIC RATS
}

\author{
Ibrahim Fattouh $^{1)}$, Sabreen Ezzat ${ }^{2)}$, shireen soliman ${ }^{3)}$ \\ ${ }^{1)}$ Department of Biochemistry, Faculty of Veterinary Medicine, \\ Kafr El-Sheikh University, Egypt \\ ${ }^{2,3)}$ Department of Biochemistry, Animal health research institute, \\ Kafr El-Sheikh branch ,Dokki ,Egypt.
}

\begin{abstract}
Diabetic nephropathy is one of the microvascular complications of diabetes mellitus. It is a life-threatening complication and occurs in 20-40\% of patients suffering from diabetes and it is the single leading cause of end stage renal disease (ESRD). This present study was designed to explore the efficiency of she camel milk or buffalo milk in controlling diabetic nephropathy. Eighty male albino rats were used in this study, divided into four groups; one group was used as a normal control group, while the remaining three groups were injected with streptozotocin in order to induce diabetes. The diabetic group was divided into Diabetic Control Group (DCG), she camel milk group (CMG) and buffalo milk group (BMG), and treated with she camel milk and buffalo milk for 4 weeks. Blood glucose was measured weekly, microalbuminuria was measured at the $4^{\text {th }}$ week and histopathological study was made at the $1^{\text {st }}$ and the $4^{\text {th }}$ week for measuring the Glomerularsclerosis index. This study revealed that there was a significant decrease in blood glucose of CMG than BMG. She camel milk group exhibited a significant improvement in microalbuminuria compared to diabetic control animals and ameliorate the pathological changes induced by diabetes. This study
\end{abstract}


documented the efficiency of she camel milk in controlling of diabetic nephropathy and improvement of kidney function. The mechanism of this effect is still unknown, so an extensive research on she camel milk is still needed to demonstrate this mechanism.

Key words: Diabetic nephropathy, she camel milk, microalbuminuria

\section{INTRODUCTION}

Diabetes mellitus is an organ specific auto immune disease, characterized by chronic hyperglycemia and disturbances of carbohydrates, fat and protein metabolism associated with insulin deficiency (Vaarala et al., 1999). Diabetic nephropathy is one of the microvascular complications of diabetes. The pathophysiology involves an interaction between metabolic and hemodynamic factors. Metabolic factors include advanced glycation, increased formation of polyols and activation of protein kinase-C. Hemodynamic factors include systemic hypertension, intraglomerular hypertension and the role of vasoactive hormones, such as angiotensin II. Clinical course progresses from microalbuminuria to overt proteinuria and then to renal failure (Annapurna et al., 2001).

In people with diabetes and/or chronic renal failure, AGEs that accumulate in the kidney are responsible for the pathological changes, including increased kidney weight, glomerular hypertrophy, glomerular basement membrane thickening, and progressive albuminuria (Vlassara et al., 1994). Moreover, AGEs stimulate free radical mechanisms and induce membrane peroxidation, which in turn increase membrane permeability (Schrijvers et al., 2004). 
The different studies were demonstrated that regular consumption of she camel milk for a few months was significantly improved the condition of diabetic patients and experimental animals (Sboui et al., 2010). Such beneficial effects of she camel milk might be due to the presence of insulin in the milk or some other substance(s) able to modulate glucose level.It contains higher level of insulin than milk of other animals (Zagorski et al., 1998). So in this study the efficiency of she camel milk was investigated to explore its effect on diabetic nephropathy.

\section{MATERIALS AND METHODS}

\section{Chemicals:}

Streptozotocin (STZ) was purchased from Sigma company.The STZ solution was prepared by freshly dissolving in citrate buffer 0.01 M ( p H 4.5) . Microalbumin standard kits were purchased from BioSystem company. PAS (periodic acid shiff) obtained from histology department, faculty of veterinary medicine, kafr elsheikh Univerisity .

\section{Animals:}

Adult Wister albino male rats between 70 - 90 days of age with body weight ranging between 80 - 100 gm were used for the study. Animals were taken from private animal house (Tanta , Egypt). Animals were maintained under standard condition (temperature $20 \pm 2{ }^{\circ} \mathrm{C}$, humidity 60 to $65 \%$ and in the $12 \mathrm{hrs}$ dark, lighting conditions). Animals were fed with standard pellet diet and had free access to water and left for 2 weeks without any treatment for acclimatization. All the ethical issues were considered based on the Kafrelsheikh University Ethical Protocols on animal experiments. 


\section{Induction of diabetes:}

Diabetes was induced by a single intraperitoneal injection of STZ at a dose of (50mg/kg body weight) (Osorio et al., 2012). The blood sample was drawn from the lateral tail vein of rats for measurment of blood glucose by portable glucometer (Bionime GM300). The blood glucose was checked at $72 \mathrm{~h}$ after STZ injection to check the development of diabetes. After one hour of STZ injection, the animals were given $5 \%$ dextrose solution in a feeding bottle for a day to overcome the hypoglycemic phase. The diabetic animals were exihibeted blood glucose levels $>250 \mathrm{mg} / \mathrm{dl}$ separated and used for the study (Azemi et al., 2012; Kumar et al., 2012) .

\section{Experimental design:}

All the diabetic animals were randomly divided into four groups with twenty animals in each group and treated once a day for 28 days as follows:

Group I : normal control group (NCG) was given only water .

Group II : diabetic control group (DCG)was given only water .

Group III : diabetic + she camel milk (CMG) at dose of $33 \mathrm{ml} / \mathrm{Kg}$.

G roup IV: diabetic + buffalo milk (BMG) at dose of $33 \mathrm{ml} / \mathrm{kg}$.

\section{Treatment:}

\section{1- She camel milk:}

She camel milk was purchased from Kafr elsheikh market, Egypt., in which she camel milk was obtained from Marsa Matrouh desert. Milk samples were collected from grazing she camels at varying stages of lactation, samples were collected in the morning during 
summer. Samples were kept in bottles surrounded by ice during transportation to the laboratory where they stored. The she camel milk was given by a dose of $33 \mathrm{ml} / \mathrm{Kg}$ b.wt daily for four weeks using stomach tube.

\section{2- Buffalo milk:}

Buffalo milk was purchased from kafr el sheikh market. Samples were kept in bottles surrounded by ice during transportation to the laboratory where they stored .The milk was administered using stomach tube at a dose of $33 \mathrm{ml} / \mathrm{Kg} \mathrm{b.wt}$. daily for four weeks.

\section{Biochemical analysis:}

The blood samples were drawn from the lateral tail vein of rats at the $1 \mathrm{st}, 2 \mathrm{nd}, 3 \mathrm{rd}$ and $4^{\text {th }}$ week for measurement of blood glucose by portable glucometer (Bionime GM300) . Urine samples were collected at the $4^{\text {th }}$ week by manual manipulation of urinary bladder then centrifuged at 3000 r.p.m. for 15 minutes for removing any debris. Urine samples were transferred into clean dry epindorff tubes and kept frozen at $-20^{\circ} \mathrm{C}$ until determination of microalbuminuria.

\section{Histopathological examination:}

Animals were sacrified at the $1^{\text {st }}$ week and $4^{\text {th }}$ week. Kidneys were quickly removed and placed in $10 \%$ formalin. The paraffin blocks of tissue prepared then cut in sections ( $1 \mu \mathrm{m}$ thick), to evaluate the possible histopathological changes of kidney tissues of the different animal groups, PAS stain were used . 


\section{Statistical analysis:}

Statistical analysis using as computer software ( Graph Pad Prism 5) to compare all analyzed characteristics. All the data were expressed as Mean $\pm \mathrm{SE}$ and represent the average values for the animals in the same group. The data were compared among and within the experimental groups. This test combines Anova with comparison of differences, among the means of the treatments at the significance level of $\mathrm{p}<0.05$.

\section{RESULTS}

\section{1-Effect of she camel milk or buffalo milk on blood Glucose level}

The levels of non-fasting blood glucose were over $250 \mathrm{mg} / \mathrm{dl}$ in diabetic control rats. Diabetic rats treated with she camel milk were showing improvement of the blood glucose nearly to the normal level at the $3^{\text {rd }}$ week and the $4^{\text {th }}$ week . Buffalo milk treatment significantly reduced the blood glucose at the $3^{\text {rd }}$ and the $4^{\text {th }}$ week but not reach to the normal level as shown in table 1and Fig. 1.

Table (1): Blood glucose levels in albino rat at $1^{\text {st }}, 2^{\text {nd }}, 3^{\text {rd }}$ and $4^{\text {th }}$ week. Data are expressed as mean \pm SE. $(\mathrm{P}<0.0001)$

\begin{tabular}{|c|c|c|c|c|}
\hline \multicolumn{4}{|c|}{ Time /week } & \\
\hline $4^{\text {th }}$ week & $3^{\text {rd }}$ week & $2^{\text {nd }}$ week & $1^{\text {st }}$ week & \\
\hline $119.5 \pm 5.63$ & $121.3 \pm 5.02$ & $126.2 \pm 4.85$ & $124.8 \pm 6.30$ & Normal \\
\hline $507 \pm 28.14$ & $502 \pm 14.46$ & $499 \pm 32.56$ & $491 \pm 42.8$ & Diabetic \\
\hline $208.5 \pm 14.11^{* * * *}$ & $244.3 \pm 65.76^{* *}$ & $326.4 \pm 65.65^{*}$ & $345.8 \pm 44.24^{*}$ & Camel milk \\
\hline $366.3 \pm 33.78^{* *}$ & $369.3 \pm 36.82^{*}$ & $406 \pm 31.64$ & $451.6 \pm 13.88$ & Bufallo milk \\
\hline
\end{tabular}

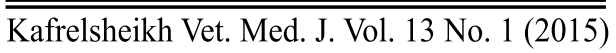


B lood glucose

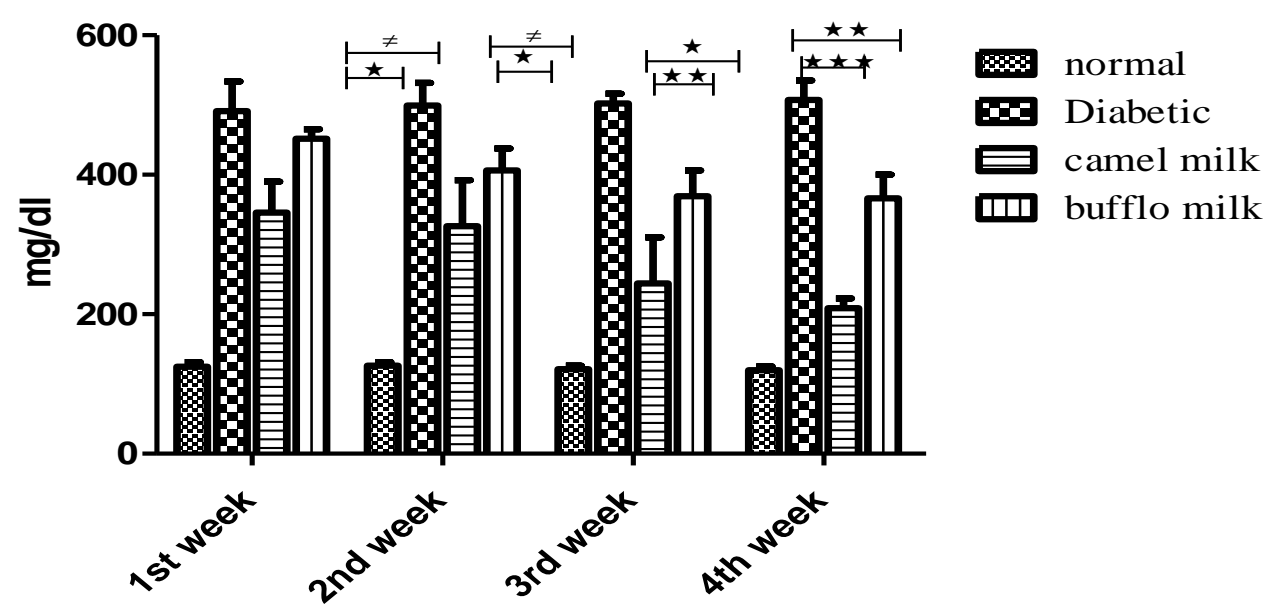

Fig. (1): Blood glucose levels in albino rat at $1^{\text {st }}, 2^{\text {nd }}, 3^{\text {rd }}$ and $4^{\text {th }}$ week. Data are expressed as mean \pm SE. $(\mathrm{P}<0.0001)$

\section{2- Effect of she camel milk or buffalo milk on microalbuminuria:}

Microalbumin was calculated at the $4^{\text {th }}$ week. There are significantly increase of microalbumin in diabetic control rats compared with normal rats. There were significantly ameliorate of microalbuminuria in she camel milk treated group nearly to the normal rats . Buffalo milk treatment significantly reduces the microalbuminuria but less than the she camel treatment as shown in table 2 and Fig. 2.

Table (2): Microalbumin levels $(\mathrm{mg} / \mathrm{dl})$ in albino rat at $4^{\text {th }}$ week . Data are expressed as mean \pm SE. $(\mathrm{P}<0.0001)$

\begin{tabular}{|c||c||}
\hline group & $\begin{array}{c}\text { Time } / \text { week } \\
\mathbf{4}^{\text {th }} \text { week }\end{array}$ \\
\hline \hline normal & $0.7396 \pm 0.2135$ \\
\hline diabetic & $2.835 \pm 0.1233$ \\
\hline camel milk & $0.9861 \pm 0.12^{* * *}$ \\
\hline bufflo milk & $2.219 \pm 0.21 \mathrm{~b}^{*}$ \\
\hline
\end{tabular}




\section{microal buminuria}

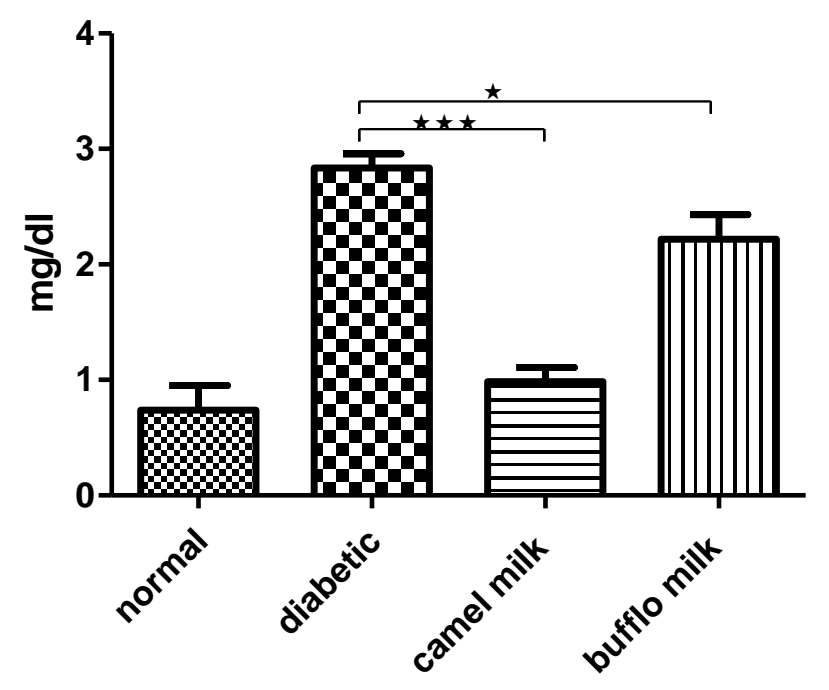

Fig. (2): Microalbumin levels $(\mathrm{mg} / \mathrm{dl})$ in albino rat at $4^{\text {th }}$ week . Data are expressed as mean \pm SE. $(\mathrm{P}<0.0001)$

\section{Histopathological findings:}

\section{Periodic acid Schiff ( PAS) accumulation}

Periodic acid Schiff (PAS) staining of the kidney tissue sections (1 $\mu \mathrm{m}$ in thickness). Accumulation of PAS-positive materials in the glomeruli was increased in the kidney section from the diabetic control at the $1^{\text {st }}$ and the $4^{\text {th }}$ week, when compared with the normal control. She camel milk, buffalo milk treatment little attenuated the deposition of the PAS-positive materials in the glomeruli but not significantly in the $1^{\text {st }}$ week . While in the $4^{\text {th }}$ week she camel milk significantly attenuated the deposition of PAS-positive materials in the glomeruli as compared with the diabetic control rats. Buffalo milk attenuated the deposition of the PAS-positive materials in the glomeruli as compared with the diabetic control rats but less than the effect of she camel milk. As shown in Fig 3. 


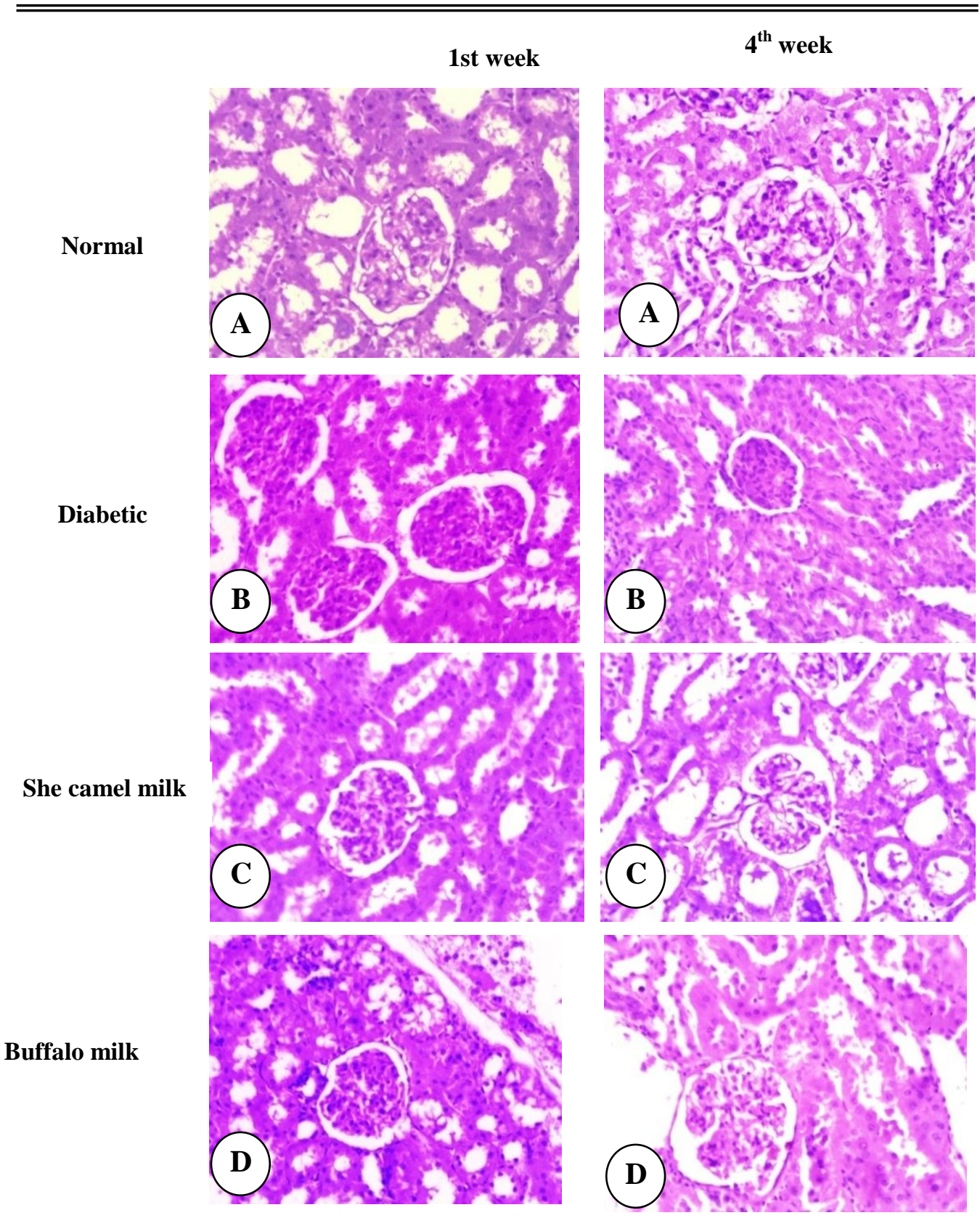

Fig (3): PAS staining of kidneys (A) : the normal group ,(B): diabetic control, C): she camel milk treated group and (D): buffalo milk treated group at $1^{\text {st }}$ week and $4^{\text {th }}$ week . 


\section{2-Glomerulosclerosis index}

Glomerulosclerosis at the $1^{\text {st }}$ week and the $4^{\text {th }}$ weeks of age was evaluated and expressed as sclerosis grade according to previous report (El Nahas et al., 1991). The sclerosis significantly increased in diabetic control rats as compared with normal rats. she camel milk and buffalo milk not reduce the glomerularsclerosis at the $1^{\text {st }}$ week compared with diabetic control group. While at the $4^{\text {th }}$ week, she camel milk and buffalo milk significantly reduce glomerularscleosis as comared with diabetic controlas shown in table 3 and Fig. 4

Table (3): Sclerosis grade levels in albino rat at $1^{\text {st }}$ and $4^{\text {th }}$ week. Data are expressed as mean \pm SE. $(\mathrm{P}<0.05)$

\begin{tabular}{|c|c|c|}
\hline \multirow{2}{*}{ Groups } & \multicolumn{2}{|c|}{ Time /weeks } \\
\hline & $\overline{\overline{1^{\text {st }} \text { week }}}$ & $\overline{\text { 4th } \text { week }}$ \\
\hline$\overline{\text { Normal }}$ & $1.453 \pm 0.12$ & $1.466 \pm 0.24$ \\
\hline Diabetic & $3.06 \pm 0.05$ & $3.699 \pm 0.12$ \\
\hline Camel milk & $2.745 \pm 0.11$ & $1.899 \pm 0.13^{* * *}$ \\
\hline Buffalo milk & $2.989 \pm 0.07$ & $2.857 \pm 0.10^{* *}$ \\
\hline
\end{tabular}
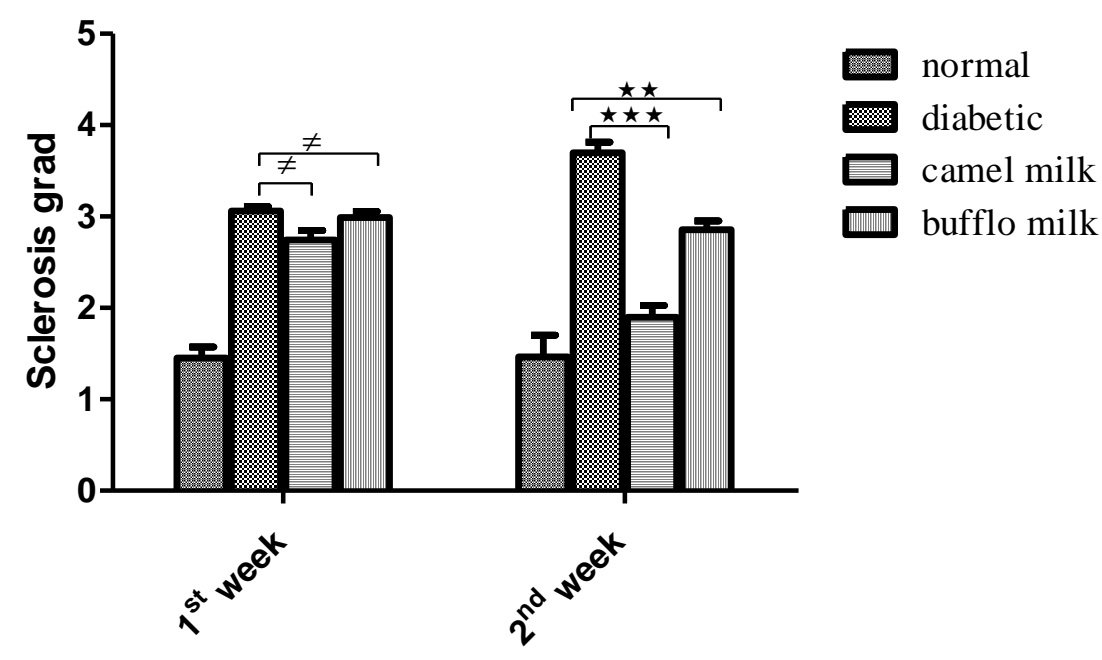

Fig. (4): Sclerosis grade levels in albino rat at 1 st and 4th week. Data are expressed as mean \pm SE. $(\mathrm{P}<0.0001)$ 


\section{DISCUSSION}

Diabetic patients with poor blood glucose control are particularly at high risk for the chronic complications (Turner et al., 1998). It is one of the most important health problems worldwide, indicating high prevalence and mortality. Management of diabetes without any side effects is still a challenge to medical communities, therefore herbal and natural products with anti-diabetic activity and fewer side effects are strongly needed (Vetrichelvan et al., 2002).

This study revealed that, she camel milk treatment was significantly decrease the blood glucose nearly to the normal level at the $3^{\text {rd }}$ week and the $4^{\text {th }}$ week, while Buffalo milk treatment reduce the blood glucose at the $3^{\text {rd }}$ and the $4^{\text {th }}$ week but not reach to the normal level this consistent with (Agrawal et al., 2004) who reported that, she camel milk has hypoglycemic effect in STZ-induced diabetic rats. In deed the improvement of blood glucose by she camel milk treatment is more than buffalo milk treatment. This concurs with (Hamad et al., 2011) who reported that, she camel milk possessed a significantly higher insulin content than both cow and buffalo milks. Insulin content in she camel milk $\left(58.67 \pm 2.01 \mathrm{U} \mathrm{L}^{-1)}\right.$ more than three folds as that of cow or buffalo milks (17.01 \pm 0.96 and $16.21 \pm 0.95 \mathrm{U} \mathrm{L}^{-1}$, respectively). This finding concurs with the results of (Shehadeh et al., 2001) who have found a high concentration of insulin $\left(\sim 52 \mathrm{U} \mathrm{L}^{-}\right)$in she camel milk.

The obvious increased insulin content in she camel milk compared with that in cow or buffalo milks may be due to ${ }^{1)}$ the she camel milk contains protein-types that possessed many characteristics similar to 
$\overline{\text { insulin as concluded by (Beg } \text { et } \boldsymbol{a l . ,}, 1986) .{ }^{2)} \text { The she camel milk does }}$ not form coagulum in acidic Environment (Wangoh and 1993), This lack of coagulum formation allows the she camel milk to pass rapidly through stomach together with the specific like protein/insulin and remains available for absorption in intestine. ${ }^{3)}$ The she camelinsulin is encapsulated in nanoparticles (lipid vesicles) that, make possible its passage through stomach and entry into circulation (Malik et al., 2012).

Our result revealed that, the She camel milk treatment significantly ameliorate of microalbumimuria nearly to normal group and this consistent with (Agrawal et al., 2005) who reported that two independent groups studied influence of regular consumption of she camel milk on diabetes and have reported reduction in urinary albumin excretion $(25.17 \pm 5.43$ vs. $14.54 \pm 5.62 \mathrm{mg} / \mathrm{dl} / 24 \mathrm{~h})$ in randomized human study.

Our result revealed that, she camel milk, buffalo milk treatment improve the pathological changes in the kidney included the sclerosis index, at the $4^{\text {th }}$ week, indeed the improvement induced by she camel milk is more than induced by buffalo milk this may due to the she camel milk has hypoglycemic effect more than buffalo milk, contain insulin content higher than buffalo milk, improve kidney function more than buffalo milk (Hamad et al., 2011).

In conclusion. this study indicated a new importance of she camel milk and new strategy for control of diabetic nephropathy and advise for daily consumption of she camel milk that may control many diseases beside the diabetes mellitus, diabetic nephropathy and other complications. 


\section{REFERENCES}

- Agrawal, R., Beniwal, R., Kochar, D., Tuteja, F., Ghorui, S., Sahani, M. and Sharma, S. (2005). She camel milk as an adjunct to insulin therapy improves long-term glycemic control and reduction in doses of insulin in patients with type-1 diabetes: a 1 year randomized controlled trial. Diabetes research and clinical practice 68, 176-177.

- Agrawal, R., Kochar, D., Sahani, M., Tuteja, F. and Ghorui, S. (2004). Hypoglycemic activity of she camel milk in streptozotocin induced diabetic rats. Int. J. Diab. Dev. Countries 24, 47-49.

- Annapurna, A., Kumar, V., Rao, N., Harish, G. and Kumar, K. (2001). Diabetic nephropathy. Ind J Pharm Sci 63, 273-278.

- Azemi, M. E., Namjoyan, F., Khodayar, M. J., Ahmadpour, F., Darvish Padok, A. and Panahi, M. (2012). The Antioxidant Capacity and Anti-diabetic Effect of Boswellia serrata Triana and Planch Aqueous Extract in Fertile Female Diabetic Rats and the Possible Effects on Reproduction and Histological Changes in the Liver and Kidneys. Jundishapur J Nat Pharm Prod 7, 168-75.

- Beg, O. U., von Bahr-Lindstrom, H., Zaidi, Z. H. and Jornvall, H. (1986). Characterization of a she camel milk protein rich in proline identifies a new beta-casein fragment. Regul Pept 15, 55-61.

- El Nahas, A. M., Bassett, A. H., Cope, G. H. and Le Carpentier, J. E. (1991). Role of growth hormone in the development of experimental renal scarring. Kidney Int 40, 29-34. 
- Hamad, E., Abdel-Rahim, E. and Romeih, E. (2011). Beneficial Effect of She camel milk on Liver and Kidneys Function in Diabetic Sprague-Dawley Rats. International Journal of Dairy Science 6.

- Kumar, S., Kumar, V. and Prakash, O. M. (2012). Antidiabetic and hypolipidemic activities of Kigelia pinnata flowers extract in streptozotocin induced diabetic rats. Asian Pac J Trop Biomed 2, 543-6.

- Malik, A., Al-Senaidy, A., Skrzypczak-Jankun, E. and Jankun, J. (2012). A study of the anti-diabetic agents of she camel milk. Int. J. Mol. Med 30, 585.

- Osorio, H., Coronel, I., Arellano, A., Pacheco, U., Bautista, R., Franco, M. and Escalante, B. (2012). Sodium-glucose cotransporter inhibition prevents oxidative stress in the kidney of diabetic rats. Oxidative medicine and cellular longevity. Volume 2012, Article ID 542042, 7 pages

- Sboui, A., Khorchani, T., Djegham, M., Agrebi, A., Elhatmi, H. and Belhadj, O. (2010). Anti- diabetic effect of she camel milk in alloxan- induced diabetic dogs: a dose-response experiment. Journal of animal physiology and animal nutrition 94, 540-546.

- Schrijvers, B. F., De Vriese, A. S. and Flyvbjerg, A. (2004). From hyperglycemia to diabetic kidney disease: the role of metabolic, hemodynamic, intracellular factors and growth factors/cytokines. Endocr Rev 25, 971-1010. 
- Shehadeh, N., Gelertner, L., Blazer, S., Perlman, R., Solovachik, L. and Etzioni, A. (2001). Importance of insulin content in infant diet: suggestion for a new infant formula. Acta Paediatrica 90, 93-95.

- Turner, R., Holman, R., Cull, C., Stratton, I., Matthews, D., Frighi, V., Manley, S., Neil, A., Mcelroy, K. and Wright, D. (1998). Intensive blood-glucose control with sulphonylureas or insulin compared with conventional treatment and risk of complications in patients with type 2 diabetes (UKPDS 33). Lancet 352, 837-853.

- Vaarala, O., Knip, M., Paronen, J., Hämäläinen, A.-M., Muona, P., Väätäinen, M., Ilonen, J., Simell, O. and Akerblom, H. (1999). Cow's milk formula feeding induces primary immunization to insulin in infants at genetic risk for type 1 diabetes. Diabetes 48, 1389-1394.

- Vetrichelvan, T., Jegadeesan, M. and Devi, B. A. (2002). Antidiabetic activity of alcoholic extract of Celosia argentea Linn. seeds in rats. Biol Pharm Bull 25, 526-8.

- Vlassara, H., Striker, L. J., Teichberg, S., Fuh, H., Li, Y. M. and Steffes, M. (1994). Advanced glycation end products induce glomerular sclerosis and albuminuria in normal rats. Proc Natl Acad Sci U S A 91, 11704-8.

- Wangoh, J. and (1993). What steps towards she camel milk technology? International Journal of Animal Science 8, 9-11.

- Zagorski, O., Maman, A., Yaffe, A., Meisler, A., Van Creveld, C. and Yagil, $R$. (1998). Insulin in milk-a comparative study. INTERNATIONAL JOURNAL OF ANIMAL SCIENCES 13, 241-244. 